\title{
UPAYA MENINGKATKAN HASIL BELAJAR IPA MENGGUNAKAN MODEL PEMBELAJARAN KOOPERATIF TIPE JIGSAW DENGAN BERBANTUAN MEDIA ALAT PERAGA KONKRET PADA PESERTA DIDIK KELAS V SDN-4
} KASONGAN BARU TAHUN PELAJARAN 2016/2017

\author{
OLEH : Agung Riadin*, Cici Liani Fitriani**
}

\begin{abstract}
ABSTRAK
Penelitian ini bertujuan untuk (1) mengetahui tentang aktivitas peserta didik dalam kegiatan belajar dengan menggunakan model kooperatif tipe jigsaw berbantuan alat peraga konkret (2) mengetahui peningkatan hasil belajar peserta didik dalam pembelajaran IPA pada materi Gaya gravitasi,gaya gesek dan gaya magnet dengan menggunakan model kooperatif tipe jigsaw berbantuan alat peraga konkret di kelas V SDN-4 Kasongan Baru Tahun Ajaran 2016/2017.

Jenis penelitian yaitu Penelitian Tindakan Kelas (PTK) subjek penelitian berjumlah 18 orang peserta didik, 6 orang laki-laki dan 12 orang perempuan. Teknik untuk mengumpulkan data menggunakan teknik observasi dan tes. Penelitian ini menggunakan alalisis dan rata-rata dan persentase ketuntasan yang di ambil dari hasil siklus pembelajaran.
\end{abstract}

Kata Kunci : Hasil Belajar, IPA,Model Jigsaw.

\section{PENDAHULUAN}

Pendidikan merupakan suatu usaha untuk menumbuh dan mengembangkan kemampuan intelektual (kognitif), sikap (afektif), dan keterampilan (psikomotorik). Pendidikan melibatkan seluruh aspek kehidupan, baik mental maupun fisik / jasmani dan sosial. Kegiatan utama pendidik yaitu sebagai proses belajar mengajar yang memiliki lima komponen. Diantaranya, peserta didik, pendidik, kurikulum, saranaprasarana dan lingkungan.

Salah satu indikasi pencapaian proses pendidikan tersebut adalah terwujudnya hasil belajar peserta didik yang memuaskan. Pendidikan dapat dikatakan berhasil apabila tercapai hasil belajar yang baik atau peserta didik mendapat nilai di atas rata-rata. Namun, peserta didik akan menemui hal-hal yang akan mendukung maupun menghambat mereka dalam mencapai prestasi belajar yang memuaskan . secara sederhana pendidikan dapatdi artikan sebagai usaha sadar manusia untuk menumbuhkan dan mengembangkan potensi diri yang dimiliki sesuai dengan nilai-nilai yang ada di masyarakat.

Menurut Ahmad D. Marimba (dalam Hasbullah, 2011: 3) pendidikan adalah bimbingan pimpinan secara sadar oleh si pendidik terhadap perkembangan jasmani dan rohani si terdidik menuju terbentuknya kepribadian yang utama. Sedangkan

Menurut Langeveld (dalam Hasbullah, 2011: 2) pendidikan idalah setiap usaha, pengaruh, perlindungan dan bantuan yang di berikan kepada anak tertuju pada pendewasaan anak itu, atau lebih tepat membentuk anak agar cukup 
cakap melaksanakan tugas hidupnya sendiri

Pendidikandiharapkanpadaduatuntu tanyaitupeningkatankualitasdanpeningkat ankuantitasterutamapadamatapelajaran IPA.Pendidikan IPA di sekolah dasar merupakan salah satu program pembelejaran yang diharapkan dapat menjadi wahana bagi peserta didik untuk mempelajari diri sendiri dan alam sekitar, serta prospek pengembangan lebih lanjut dalam menerapkannya di dalam kehidupan sehari-hari. Proses pembelajarannya menekankan pada pemberian pengalaman langsung untuk mengembangkan kompetensi agar menjelajahi dan memahami alam sekitar secara ilmiah. Pendidikan IPA diarahkan untuk berbuat sehingga dapat membantu peserta didik untuk memperoleh pemahaman yang lebih mendalam tentang alam sekitar. (Depdiknas 2006).

Keberhasilan pembelajaran IPA ditentukan oleh bagaimana guru dalam perencanaan, pelaksanaan dan menilai sesuai dengan tujuan yang telah ditetapkan. Pembelajaran IPA disekolah dasar masih ditemukan berbagai masalah antara lain bahwa hasil pembelajaran IPA masih kurang baik sebagai akibat kurang baiknya sistim evaluasi dan metode pembelajaran yang monoton tidak bervariasi, membosankan yang menekankan pada mengingat dan memahami saja. Sehubungan dengan hal tersebut pembelajaran IPA Pada umumnya hanya pada pemberian pengetahuan (Kognitif) belum pada apektif dan psikomotor peserta didik. Kurang optimalnya pembelajaran IPA ini juga terjadi diSDN - 4Kasongan Baru kelas $\mathrm{V}$ tempat penulis melakukan penelitian.

Berdasarkan observasi dan wawancara dengan guru kelas V SDN - 4
Kasongan Baru pada tanggal 23 januari 2017,

bahwakurangnyaperhatianpesertadidikketi kasedangmengikuti proses belajarmengajaratauketika guru sedangmenjelaskan, selainitupenelitimelihattidakada model mengajar yang guru gunakandanmasihmonoton, guru belummenggunakan model pembelajarandikarnakan media yang kuranglengkap yang masihbelumtersediadisekolahtersebut.

Sehingga guru pada saat proses belajar mengajar belum menggunakan metode yang bervariasi atau menggabungkan dengan model pembelajaran lainnya yang lebihmenarik. Dari data hasil belajar IPA peserta didik yang di dapatkan dari wali kelas V SDN-4 Kasongan Baru pada ulangan harian dengan jumlah peserta didik 18 orang, dimana 6 orang peserta didik sudah mencapai KKM dengan nilai rata-rata di atas 60 dan 12 orang peserta didik masih belum mencapai KKM dengan nilai rata-rata di bawah 60, sedangkan KKM yaitu 60. Oleh sebab itu penelitimerasa perlu melakukan percobaan pada mata pelajaran IPA.

Proses pembelajaran dalam Kurikulum Tingkat Satuan Pendidikan (KTSP) menuntut adanya partisipasi aktif dari seluruh peserta didik. Jadi, kegiatan belajar berpusat pada peserta didik, guru sebagai motivator dan fasilitator didalamnya agar suasana kelas lebih hidup.Sehubungandenganpermasalahandi atas,diperlukansuatualternatifuntukdapat memperbaikikondisi proses tersebut,salahsatunyadenganPembelajaran kooperatif terutama teknik Jigsaw dianggappeneliti cocok diterapkan dalam pembelajaran IPA. 
Dalampenelitianinipenelitimenggun akanmetodePenelitianTindakanKelas( PTK ) karenapenelitianini di gunakanuntukmemperbaikiataumeningkat kanhasilbelajarpadapesertadidik, khususnyapadamatapelajaran IPA.

MenurutArikunto (2010:3) "penelitian tindakan kelas merupakan suatu pencermatan terhadap kegiatan belajar berupa sebuah tindakan yang disengaja dimunculkan dan terjadi dalam sebuah kelas secara bersama". Sedangkan menurut Wibawa (Sanjaya, 2010 :5) "penelitian tindakan kelas merupakan suatu penelitian yang mengangkat masalah-masalah aktual yang di hadapi oleh guru di lapangan".

Jadi dapat di simpulkan bahwa penelitian tindakan merupakan proses belajar mengajar yang dilaksanakan secara sistematikdan menggunakan teknik teknik yang relevan.

Teknik Pengumpulan data di lakukan dengan menggunakan teknik observasi dan tes.

a. Observasi

Observasi adalah pengumpulan data melalui pengamatan langsung di lapangan terhadap hal-hal yang berhubungan dengan penelitian. Observasi bertujuan untuk mengamati secara langsung kegiatan belajar mengajar di ruang kelas V SDN 4 Kasongan Baru pada mata pelajaran IPA.

Menurut Sugiyono (2007 : 203) bahwa "tekni pengumpulan data dengan observasi digunakan bila peneliti berkenaan dengan prilaku manusia, proses kerja, gejala-gejala alam dan responden yang diamati tidak terlalu besar".

b. Tes Teknik tes dilakukan untuk mengukur tingkat penguasaan dan kemampuan peserta didik secara individual dalam cakupan dan ilmu pengetahuan yang telah di berikan oleh guru.

Menurut Margono (Neti setyaningsih,2014:33) tes adalah "alat atau prosedur yang di pergunakan dalam rangka pengukuran dan penilaian saat di laksanakannya atau peristiwa berlangsungnya pengukuran dan penilaian". Sedangkan Rasyid dan Mansur (2008:11) menyatakan bahwa :

Tes adalah sejumlah pernyataaan yang membutuhkan jawaban atau sejumlah pertanyaan yang harus di berikan tanggapan dngan tujuan mengukur tingkat kemampuan seseorang atau mengungkapkan aspek tertentu dari seorang yang di kenai tes.

Berdasarkan pengertian di atas dapat disimpulkan bahwa tes merupakan sejumlah pertanyaan atau alat instrumen yang di berikan untuk mengukur tingkat kemampuan seseorang.

Teknik analisis data, Adapun teknik-teknik pengumpulan data yang di gunakan dalam

usaha pengumpulan data mengenai masalah pemesahan yang akan diteliti. Pada penelitian ini menggunakan teknik analisis data kualitatif dan kuantitatif.

\section{HASIL DAN PEMBAHASAN}

Deskripsi data pre tes merupakan hasil belajar yang di peroleh dari nilai soal pre tes sebelum di berikan perlakuan. Data pre tes ini bertujuan untuk mengetahui kemampuan awal peserta didik terhadap materi gaya gravitasi,gaya gesek dan gaya magnet. Pre test dilaksanakan pada hari rabu tanggal 19 April 2017 pukul 07.15 - 08.00. Hasil data pre tes ini akan menjadi tolak ukur keberhasilan terhadap pembelajaran yang akan di lakukan, soal pre tes yang diberikan berjumlah 20 butir soal dalam 
bentuk pilihan ganda. Rata-rata hasil belajar IPA pree tes yaitu57, dan ketuntasanya $28 \%$ yang berarti hasil belajar peserta didik masih rendah dan masih banyak peserta didik mendapat nilai di bawah KKM, sehingga perlu adanya tindakan kelas untuk meningkatkan hasil belajar IPA peserta didik dengan menggunakan model pembelajaran jigsaw.

Berdasarkan hasil post tes siklus I terlihat hasil belajar IPA peserta didik kelas V SDN-4 Kasongan Baru dengan rata-rata 80,83 dan ketuntasan $94 \%$ termasuk dalam kriteria sangat tercapai, tingkat ketercapaian keberhasilan pembelajaran sudah memenuhi syarat ketuntasan klasikal.

Pada tahap pra tindakan membuktikan bahwa rendahnya kemampuan peserta didik dalam menjawab soal yang di berikan, hal tersebut di lihat dari hasil pre test yang persentase ketuntasan klasikal hanya mencapai $28 \%$ dari 18 peserta didik hanya 5 orang peserta didik yang mendapat nilai sesuai dengan KKM. Sementara pada siklus I hasil belajar post test peserta didik sudah mencapai ketuntasan, hal ini sangat terlihat pada peningkatan hasil belajar IPA peserta didik. Ketuntasan klasikal mencapai 94\% , dari 18 peserta didik 17 peserta didik sudah mendapatkan nilai sesuai dengan KKM.

Dari hasil yang di dapat baik secara kualitatif maupun kuantitatif ternyata kegiatan pada siklus I sudah mencapai angka prestasi ketuntasan yang di tentukan yaitu $85 \%$. jadi, penelitian ini di anggap sudah dapat meningkatkan hasil belajar dan penelitian ini selesai pada siklus I.
Aktivitas peserta didik kelas $\mathrm{V}$ di SDN-4 Kasongan Baru sangat tinggi dalam proses pembelajaran IPA pada materi Gaya gravitasi,gaya gesek dan gaya magnet dalam penggunakan model koopertatif tipe jigsaw dengan berbantuan media alat peraga konkret. Terlihat dari jumlah skor nilai aktivitas peserta didik pada siklus I dengan nilai rata-rata 3,90 yaitu kategori baik.

Ada peningkatan hasil belajar IPA dalam materi gaya gravitasi,gaya gesek dan gaya magnet dalam menggunakan model pembelajaran kooperatif tipe jigsaw dengan berbantuan alat peraga konkret padakelas V SDN-4 Kasongan baru. Peningkatan tersebut dapat dilihat dari hasil belajar peserta didik. Pada pra tindakan perolehan rata-rata peserta didik 57dengan ketuntasan klasikal 28\%. Setelah penerapan model kooperatif tipe jigsaw meningkat pada siklus I perolehan nilai rata-rata peserta didik 81 dengan ketuntasan klasikal 94\%

\section{DAFTAR PUSTAKA}

Arikunto, Suharsimi, (2006). Prosedur Penelitian Suatu PendekatanPraktis. Jakarta: PT. Rineka Cipta.
Hasbullah.2011. Dasar-Dasar Ilmu Pendidikan. Jakarta: PT RajaGrafindo Persada. Margono.2003. metedologipenelitian pendidikan.Jakarta:Rineka Cipta

$\begin{array}{lr}\text { Sanjaya,Wina. } & \text { 2013. } \\ \text { Pembelajaran } & \text { Berorientasi } \\ \text { Standar Proses } & \text { Pendidikan. } \\ \text { Jakarta kencana prenada media } \\ \text { grup. }\end{array}$

\section{KESIMPULAN}


Pedagogik Jurnal Pendidikan, Oktober 2018, Volume 13 No 2 (1-5)

Agung Riadin* Dosen UM Palangkaraya 